\title{
Geochemical Features of Oil on Biomarkers
}

\author{
G.S. Martynova ${ }^{1}$, F.R. Babaev ${ }^{2}$, O.P. Maksakova ${ }^{1}$,R.G. Nanadzhanova ${ }^{1}$ \\ 1- The Institute of Oil and Gas \\ 2 - Azerbaijan Technical University
}

\begin{abstract}
Annotation: Here are presented the data of GC / MS, ICP / MS, UV, STA studies of Azerbaijanoil from the Gunashli field in the Caspian Sea. According to the data of chromatography-mass spectroscopy, the relative distribution of n-alkanes of oil was determined to calculate the naphthenic oil passport from various horizons and depths. It is shown that oil is of paraffin-naphthenic type, hydrocarbon composition of oil samples varies depending on the horizon and the depth of occurrence. Oil is characterized as light, average catagenetic transformation and refers to the glandular type. Mother rock of sedimentary type are of the clay type. The studied geochemical characteristics of oil indicate a biogenic genesis and differentiation of oils by characteristic biomarker indicators, and also make it possible to predict the composition and type of oils in deposits with a simular geological structure.
\end{abstract}

Keywords:oil biomarkers, diagenetic transformation, GC/MS, ICP / MS, oil

\section{Introduction}

The hydrocarbon composition of oil in the reservoir can vary due to the processes occurring during migration, mixing of oils of different genesis, and also as a result of biodegradation. In this regard, studying of genesis and interpretation of the geochemical features of oil are of a great interest.Fractional hydrocarbon (HC) and microelement (ME) compositions, as well as geochemical characteristics-oil biomarkers by combined thermal analysis, chromatography-mass spectrometry, ultraviolet spectroscopy, and elemental analysis, have beenstudied in the case of the Gunashli field in Azerbaijan [1].

The Gunashli field in the Caspian Sea was discovered in 1981, and since 2008, production began at the deep-water part of the field. At this deposit, oil and gas condensates of industrial importance were discovered in the following horizons and retinues of the lower pliocene of the productive stratum: $\mathrm{KaC}_{3}, \mathrm{KaC}$, NKP, SP, $\mathrm{BS}$ (X, IX, VI, V) horizons. The agreement on the exploration and development of the deepsea part of Gunashli was signed in 1994 between the government of the Republic of Azerbaijan and the international consortium [2].

\section{Experimental part}

There have been studied samples of oils taken from wells with the different depths and various horizons: well No. 135 (X horizon, filter-3148-3084 m), well No. 136 (X horizon, filter 2990-2980 m), No. 212 (IX horizon, filter-3000-2940m), well No. 293 (IX horizon, filter-2987-2907m), well No. 244 (retinue suite, filter2998-2972m), well No. 250 (retinue suite, filter-3024-2983m).

The biomarker analysis of the oil was carried out by using chromatography-mass spectrometry method, (A chromatography-mass spectrometer-Clarus 680 Perkin-Elmer), which is equipped with an interface with a highly effective mass-selective detector Clarus SQ8T. Chromatograms of hydrocarbons were obtained from the "Total Ion Current" (TIC) and "Selected Ion Recording(SIR). The identification of individual hydrocarbons was carried out by means of a computer search in NIST-08, based on literature data, and by reconstruction of structures based on the nature of ion fragmentation during electron impact.The ME measurements of the composition of the oil samples were carried out by induction-coupled plasma mass spectroscopy on "Perkin Elmer ICP / MS" instrument. The detection limits for most elements are $<0.001 \mathrm{~g} / \mathrm{t}$.

UV spectroscopic studies of oil samples were obtained on a "Perkin Elmer, LAMBDA UV" spectrometer by using quartz cuvettes with an optical path length of $10 \mathrm{~mm}$; samples of native oil for optical studies were prepared by dissolution in hexane and isooctane. Analysis of the fractional composition of oil was carried out by combined thermal analysis on "STA 6000, Perkin Elmer" apparatus in an inert atmosphere.

\section{Theoretical part}

For oil-oil correlation, it is necessary to use the fullest possible set of specific biomarkers (normal alkanes, isoprenoids, saturated polycyclic hydrocarbons - steranes, terpanes) for a particular deposit -, "fingerprints" of this oil. However, for the correlation constructs, the most important are the terpanes and steranes C29: 20S / 20R - $\alpha \beta \beta(\mathrm{R}) / \alpha \alpha \alpha(\mathrm{R})$ [3]. For a positive oil-oil correlation, a large number of unusual characteristics is needed; only one important difference between the samples is sufficient for negative correlation, for example: lack of 28,30-bisnorhopane; 25,28,30-trisnorhopane and steranes of C30 the 
composition. The age of the oil and its genesis can be judged from the ratio of the steranes $\mathrm{C} 27$ : $\mathrm{C} 28$ : $\mathrm{C} 29$; $\mathrm{C} 27$ : $\mathrm{C} 28$; 28 : C29; tri / penta, or by the distribution of adamantanes (C11 / C13; $\mathrm{C} 12$ / C13).

At present, the ratio of the $\mathrm{C} 28$ / $\mathrm{C} 29$ steranes is used as the factor determining the geological age of the initial OM [4 -6]. According to the generalized data of Chakhmakchev, the parameters C28 / C29 clearly separate the Precambrian and Paleozoic (0.2-0.6) from Mesozoic-Cenozoic (0.6-1.2). The increase in the share of C28 occurs not due to the chemical evolution of the steranes, but to the expansion of species features of phytoplankton at a later geological time.

Steranes originate from sterols, which are typical for most higher plants and algae, but rare or absent in prokaryotic organizations. Cholesterol prevails in zooplankton. The source of ergostane (C28) is phytoplankton. An example is the Azerbaijan oil from the Darwin Kyupasi field - C27: C28: C29 = 23: 36: 15. Ergostane in it accounts $-36 \%$, therefore, in this case, the formation of steranes occur due to phytoplankton.Sterane C29 stigmastane, is synthesized by higher terrestrial plants and some species of marine algae. It can be assumed that it is formed by the same way as $\mathrm{C} 28$.

Marine organisms in the process of transformation of the buried OM are transformed into $\mathrm{C} 27$ sterane, and higher terrestrial plants synthesize C29 sterane.Some species of seaweed are also rich in C29 sterane, which is explained by the peculiarities of the microflora of blue-green algae.The C27-zooplankton-cholestanes, C28phytoplankton-ergostanes, C29-higher terrestrial plants-sitostanes.

\section{Results and discussions}

Hydrocarbon data (Table 1) and fractional composition of oil samples were obtained by complex studies, depending on the horizons and depth of occurrence, biomarkers such as pristane, phytane, oleanane, tri-, tetra-, pentacyclic terpanes, steranes, hopanes(Table 2), and were defined their trace element composition was studied as well .The ICP / MS data showed that the Gunashli oil is of a ferrous type. Fig. 1 shows Fe distribution along the wells of the Gunashli field.

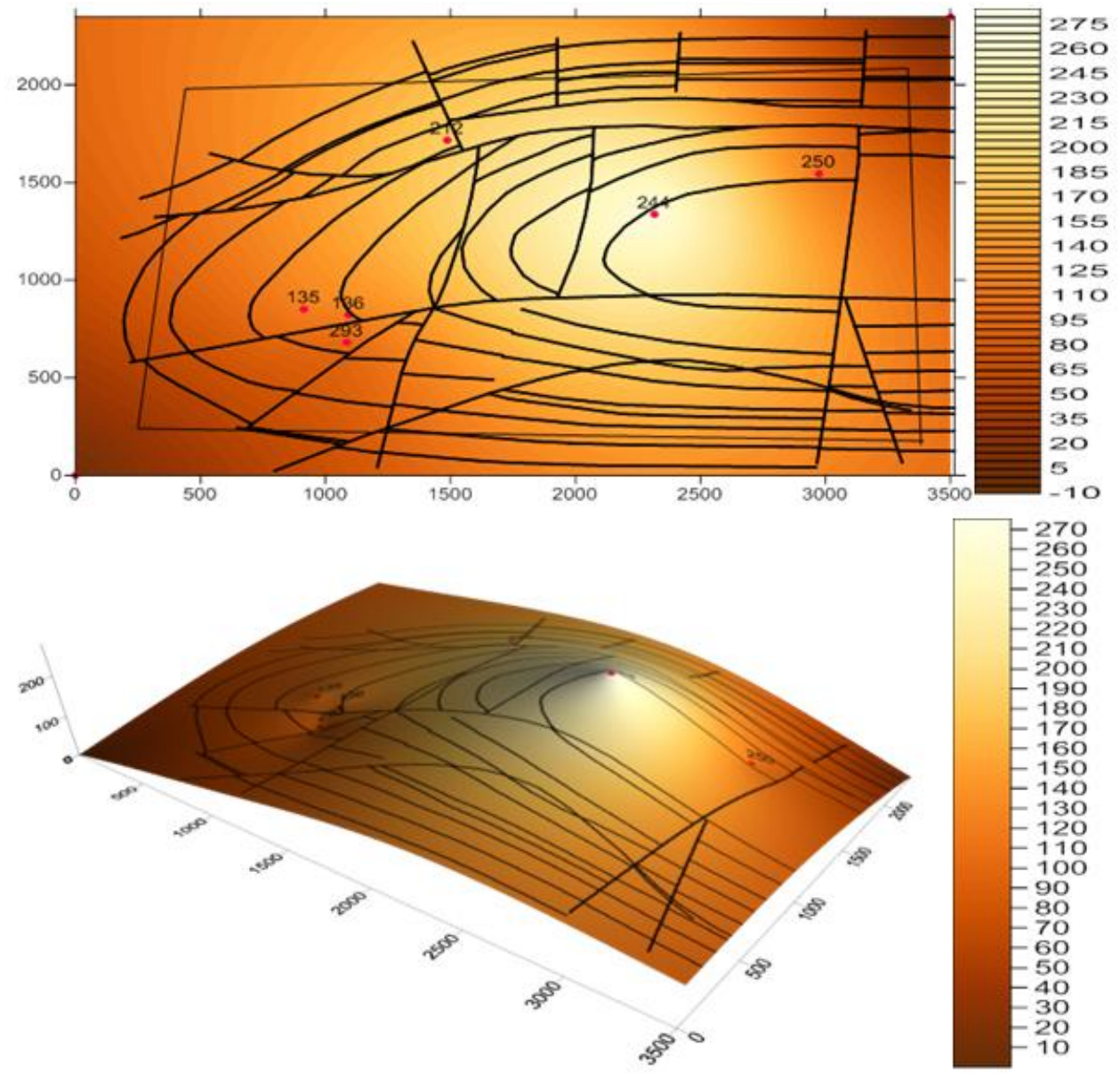

Figure 1. Distribution of iron Fe in the wells of the Gunashli field 
Characteristics of the Gunashli field oil according to GC / MS

Tabl.1

Geochemical characteristics of the oil fieldGunashli on biomarkers

\begin{tabular}{|l|l|l|l|l|l|l|l|}
\hline \multirow{2}{*}{$№$} & Gunashli & \multirow{2}{*}{$\begin{array}{c}\text { Depth / } \\
\text { № well. }\end{array}$} & Horison & \multicolumn{2}{l|}{ HC composition \% relat. } & \multirow{2}{*}{ Pr/Ph } & CPI \\
\cline { 3 - 6 } & 293 & $2987-2907 / \mathrm{IX}$ & 58,43 & 34,74 & 4,83 & 1,21 & 1,26 \\
\hline 1 & 212 & $3000-2940 / \mathrm{IX}$ & 48,52 & 42,47 & 9,01 & 1,23 & 1,20 \\
\hline 2 & 136 & $2990-2980 / \mathrm{X}$ & 69,61 & 24,58 & 5,91 & 1,22 & 1,04 \\
\hline 3 & 135 & $3148-3084 / \mathrm{X}$ & 66,05 & 29,55 & 4,4 & 1,14 & 1,04 \\
\hline 4 & 244 & $\begin{array}{l}2998-2972 / \\
\text { retinue suite }\end{array}$ & 64,72 & 26,88 & 8,6 & 1,14 & 1,16 \\
\hline 5 & $\begin{array}{l}3024-2983 / \\
\text { retinue suite }\end{array}$ & 71,67 & 22,4 & 6,29 & 1,14 & 1,03 \\
\hline 6
\end{tabular}

Tabl.2

\begin{tabular}{|l|l|l|l|l|l|l|l|l|l|}
\hline № & $\begin{array}{l}\text { Gunashli } \\
\text { № well. }\end{array}$ & $\begin{array}{l}\text { Depth/ } \\
\text { Horison }\end{array}$ & Ts/Tm & H29/H30 & Oleanane/H30 & neoC29/hC29 & H27:H29:H30:H31 & tri/penta & tetra/tri \\
\hline 1 & 293 & $2987-2907 / \mathrm{IX}$ & 1.06 & 0.37 & 0.05 & 0.2 & $3: 12: 30: 16$ & 0.23 & 6.27 \\
\hline 2 & 212 & $3000-2940 / \mathrm{IX}$ & 1.15 & 0.39 & 0.05 & 0.23 & $3: 12: 30: 16$ & 0.16 & 9.26 \\
\hline 3 & 136 & $2990-2980 / \mathrm{X}$ & 0.85 & 0.4 & 0.05 & 0.16 & $4: 13: 32: 16$ & 1.19 & 9.13 \\
\hline 4 & 135 & $3148-3084 / \mathrm{X}$ & 0.82 & 0.4 & 0.04 & 0.2 & $4: 13: 32: 16$ & 0.3 & 5.12 \\
\hline 5 & 244 & $\begin{array}{l}2998-2972 / \\
\text { retinue suite }\end{array}$ & 0.99 & 0.38 & 0.05 & 0.18 & $3: 11: 29: 16$ & 0.59 & 2.61 \\
\hline 6 & 250 & $\begin{array}{l}3024 \\
\text { retinue suite }\end{array}$ & 0.97 & 0.41 & 0.05 & 0.15 & $3: 12: 30: 16$ & 0.43 & 3.21 \\
\hline
\end{tabular}

As can be seen from the experimental data, the hydrocarbon composition changes in oil samples depending on the depth and horizon. Thus, with increasing sampling depth, the amount of alkane hydrocarbons increases, while the amount of naphthenic HC decreases. The pristane / phytane ratio $(\mathrm{Pr} / \mathrm{Ph})$ is considered as one of the main genetic indicators bearing information about the peculiarities chemical composition of the original living matter. The close content or predominance of $\operatorname{Pr}$ over $\mathrm{Ph}(\sim 1.14 \div 1.23)$ is due to the reducing conditions of sedimentation.

The oddity index, Carbon Preference Index, $\mathrm{CPI}=(\mathrm{C} 17+\mathrm{C} 19)+(\mathrm{C} 19+\mathrm{C} 21 / 2 \cdot(\mathrm{C} 18+\mathrm{C} 20)$ serves to assess for the maturitydegree assessment. Same as for the oil of the Gunashli field $\mathrm{CPI}=1.03 \div 1.26$, which corresponds to the maximum of oil generation (Fig. 2).

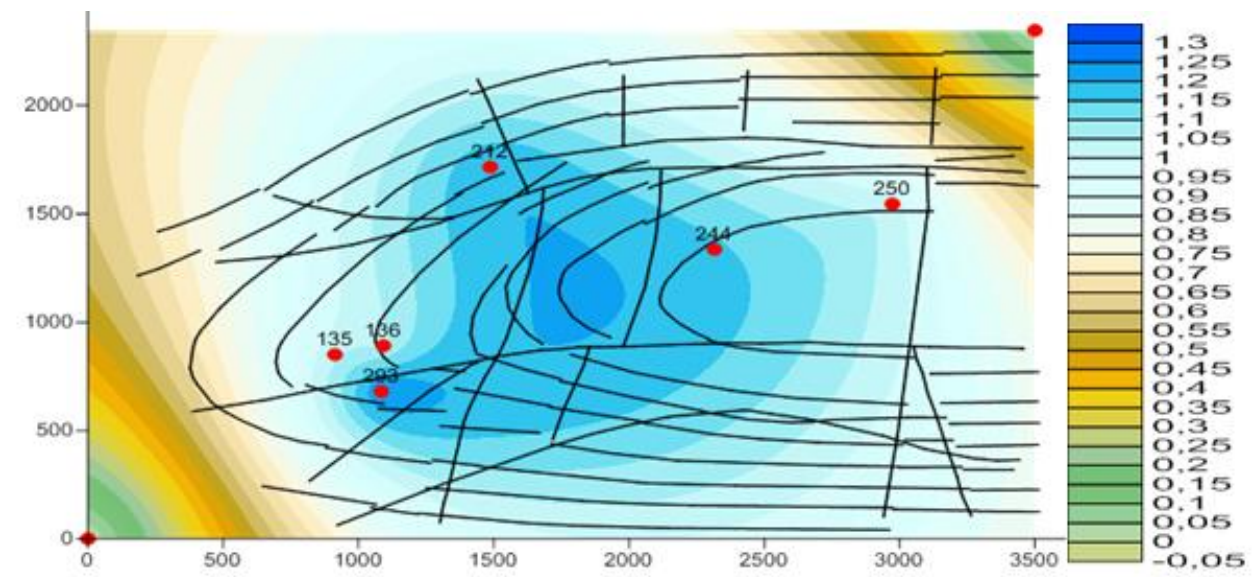




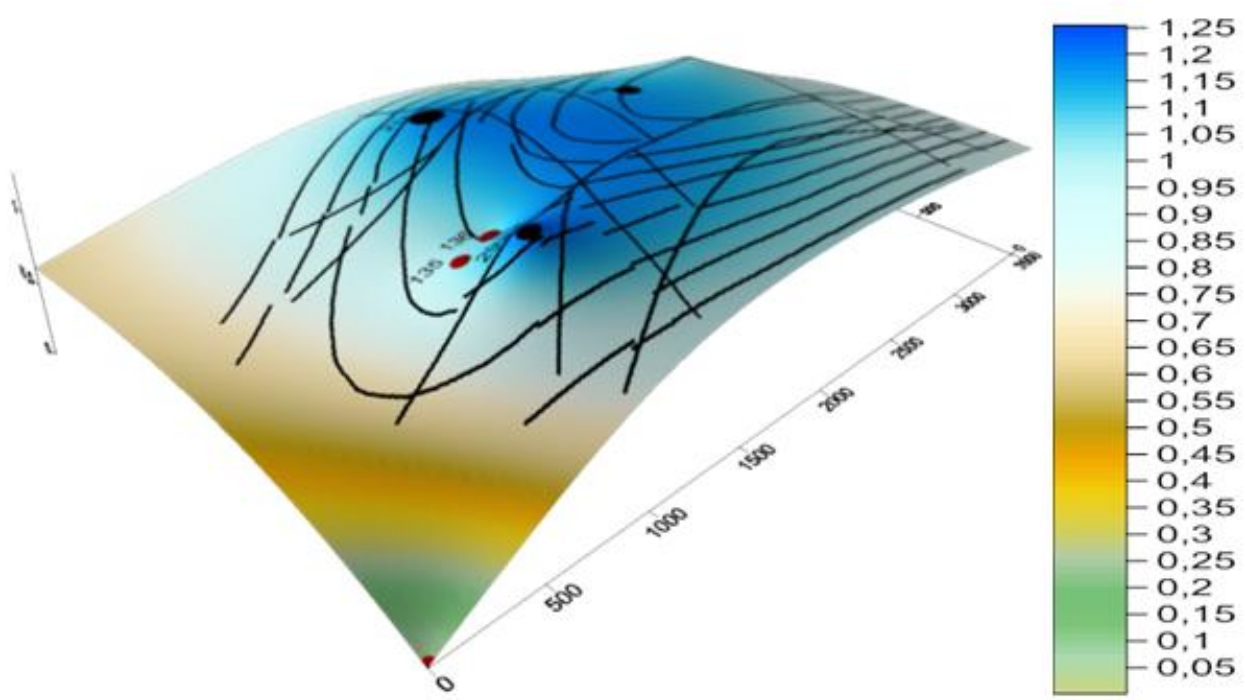

Fig. 2. Distribution of CPI for oil wells of Gunashli field

The ratio of the more stable trisnoreneohopane to the less stable trisnorehopane - Ts / Tm or terpane index - determines the maturity, sedimentation conditions and characterizes the degree of catagenetic transformation of the oil. Judging by the values of the terpane index, as well as the tri / penta ratio - oil of the Gunashli field is less mature. The calculated ratios of geochemical characteristics for steranes are close [1]. The maximum is mainly accounting for C28 and C29 sterols, methyl and ethyl-cholestanes, and reflects oils age so if the ratio is $>0.7$, apparently, there is proceeding an increase in the species of phytoplankton in the JurassicCretaceous period. The ratios of C28 / C29 and dia / reg steranes decrease in oil samples from IX, X horizons to the retinue suite. At the same time, the values of the sterane parameter dia / reg allow us to judge the clayiness of the oil-mother sedimentary rocks. When considering the ratio of C27: C28: C29 steranes, it was noted that the IX horizon is characterized by the predominance of C27, C28 steranes, indicating a predominance of phyto- and zooplankton, for $\mathrm{X}$ horizon and break - C28, C29, indicating the prevalence of zooplankton and terrestrial plants in the genesis of oil.Judging by the ratio of steranes in the investigated oils, the formation of OM was mixed (continental-marine or coastal). The studied geochemical characteristics of oil indicate a biogenic genesis and differentiation of oils by characteristic biomarker indicators.

As is known, the naphthenic passport is inherited by oil from the original organic matter $(\mathrm{OM})$ and can also be used as a criterion for establishing the genetic relationship between oils and rock OM [7].Genetically linked oils of various chemical compositions illustrate the identity of naphthenic passports. Below are the data of chromatography-mass spectroscopy (Fig. 3, 6,9), the relative distribution of n-alkanes for oil (Fig. 4, 7, 10) for the calculation of the naphthenic oil passport of the Gunashli field (Fig. 5,8,11), from various horizons and depths of occurrence.

The nature of the naphthenic passports of the studied oils is very diverse, and for each region there are certain specific features. For example, in the oils of the Gunashli field, mono- and tetracyclic naphthenic hydrocarbons predominating in quantitative terms, which is not observed in the oils of other regions. While, for example, bi-and tetracyclic naphthenic hydrocarbons prevail in the oils of the Southern Caspian. Comparison of naphthenic oil passports of different regions makes it possible to reveal in them the features of simularity and difference.

Judging by the component composition, the Gunashli field oil is of a paraffin-naphthenic type. If the oil is paraffin-naphthenic, then, as a rule, the aromatic content is small, judging from the UV spectroscopy data $\sim 6 \div 10 \%$. The samples from the Gunashli field contain a significant proportion of the light part, with the predominance of kerosene-gas oil fraction, according to the STA method, and it can be characterized as light, medium catagenetic transformation. 

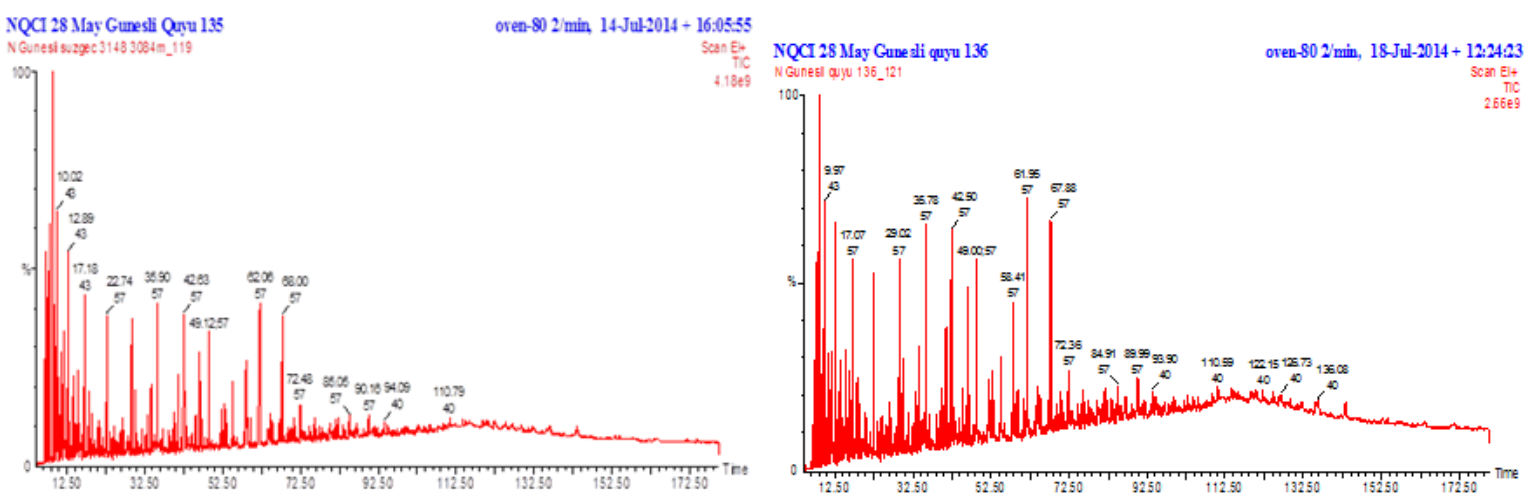

Fig.3. Chromatograms of oil from Gunashlisquare.135, 136
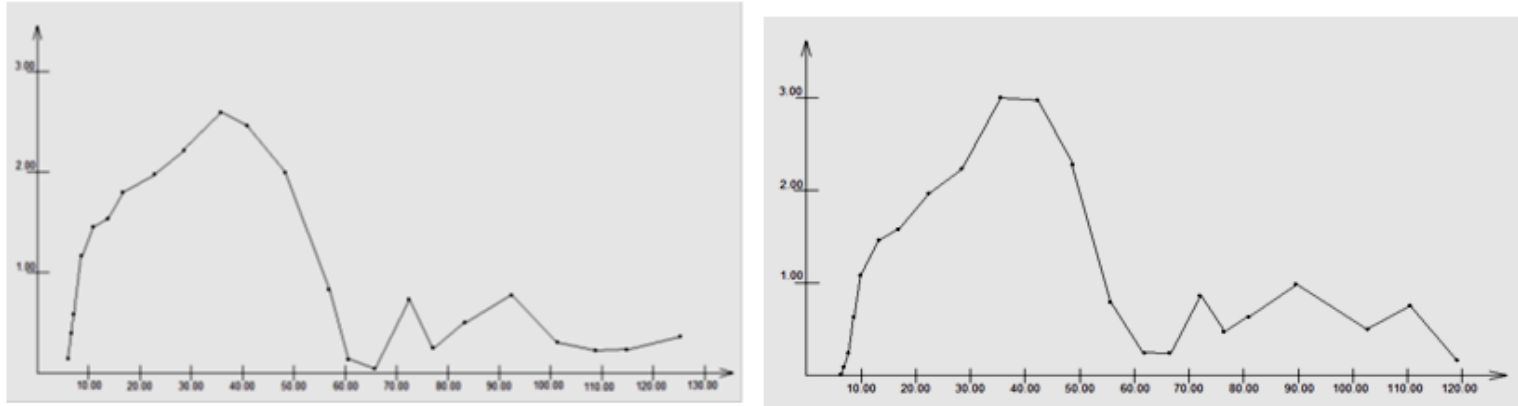

Fig.4. The relative distribution of n-alkanes for oil (wells.135, 136)

\begin{tabular}{|c|c|c|c|c|c|}
\hline \multirow{2}{*}{ Name } & \multicolumn{5}{|c|}{ Naphthens HC } \\
\cline { 2 - 6 } & mono & bi & tri & tetra & penta \\
\hline $\begin{array}{c}\text { Gunashli } \\
135\end{array}$ & 82.33 & 1.41 & 4.01 & 10.84 & 1.41 \\
\hline
\end{tabular}

\begin{tabular}{|c|c|c|c|c|c|}
\hline \multirow{2}{*}{ Name } & \multicolumn{5}{|c|}{ Naphthens HC } \\
\cline { 2 - 6 } & mono & bi & tri & tetra & penta \\
\hline $\begin{array}{c}\text { Gunashli } \\
136\end{array}$ & 83.81 & 3.17 & 0.16 & 6.95 & 5.9 \\
\hline
\end{tabular}

Fig.5. The naphthenic oil passport of Gunashlisquare - 135, 136
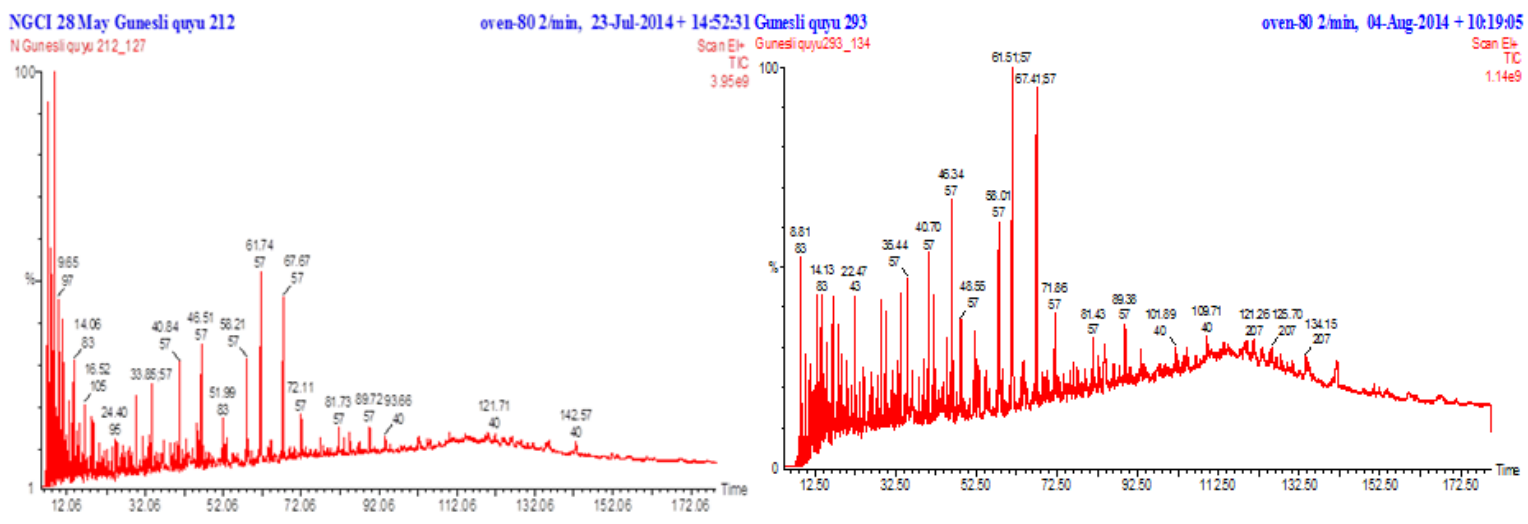

Fig.6. Chromatograms of oil from Gunashli - wells. 212, 293
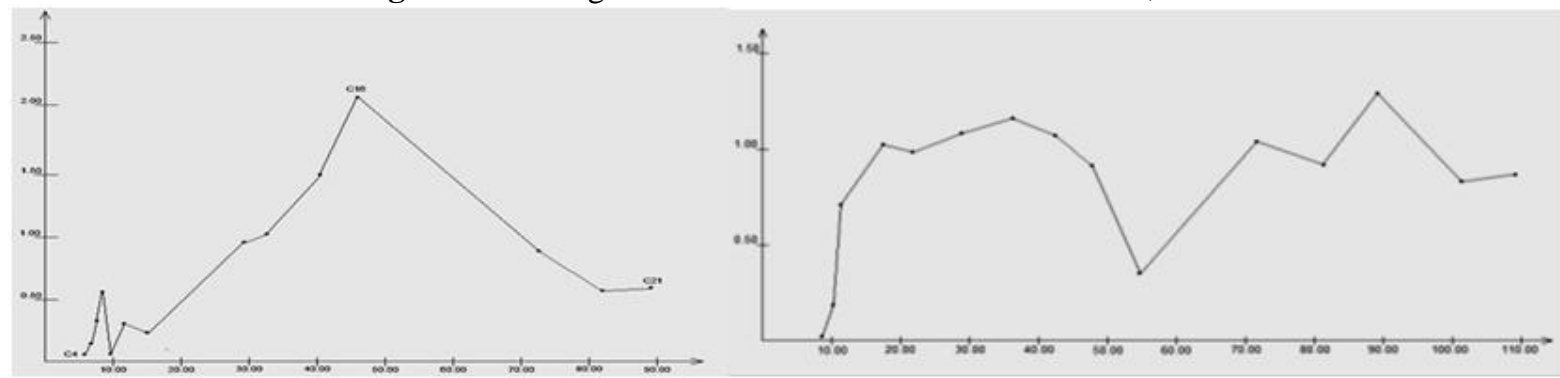

Fig.7. Relative distribution of n-alkanes for oil - wells. 212, 293 
Geochemical Features of Oil on Biomarkers

\begin{tabular}{|c|c|c|c|c|c||c|c|c|c|c|c|}
\hline \multirow{2}{*}{ Name } & \multicolumn{4}{|c|}{ Naphthenic HC } & \multicolumn{3}{|c|}{ Name } & \multicolumn{5}{|c|}{ Naphthenic HC } \\
\cline { 2 - 8 } & mono & bi & tri & tetra & penta & & mono & bi & tri & tetra & penta \\
\hline $\begin{array}{c}\text { Gunashli } \\
212\end{array}$ & 88.2 & 3.78 & 4.79 & 0 & 3.23 & $\begin{array}{c}\text { Gunashli } \\
293\end{array}$ & 75.19 & 7.94 & 0 & 10.51 & 6.36 \\
\hline
\end{tabular}

Fig.8. The naphthenic oil passport of Gunashli square - 212, 293

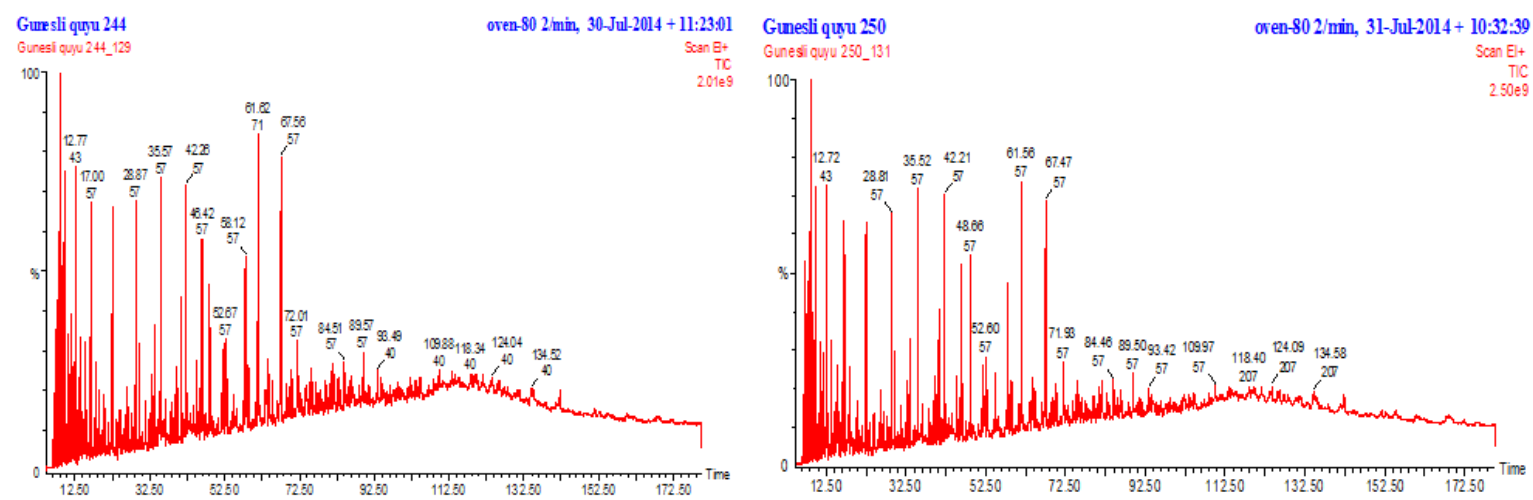

Fig. 9. Chromatograms of oil from Gunashli square - 244, 250
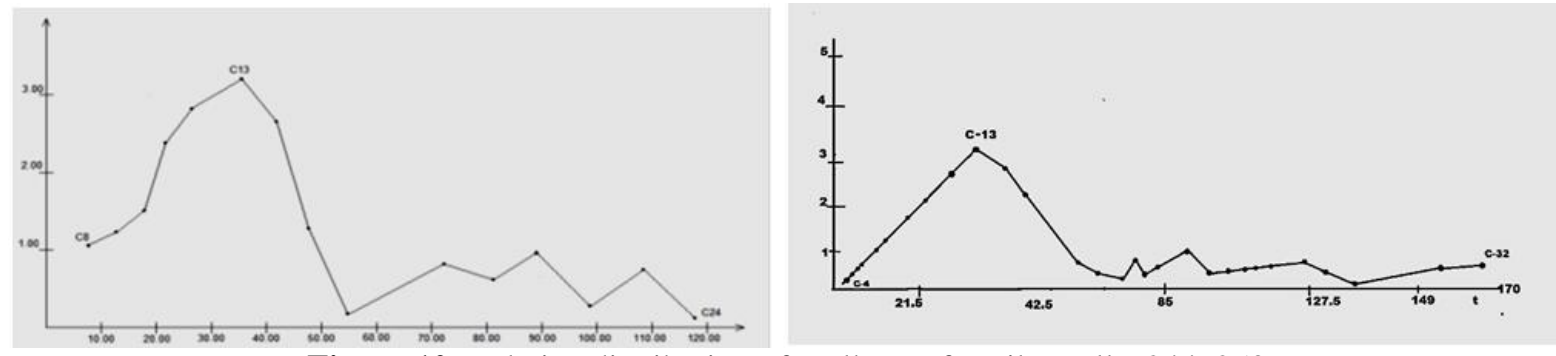

Figure 10. Relative distribution of n-alkanes for oil - wells. 244, 250

\begin{tabular}{|c|c|c|c|c|c|}
\hline \multirow{2}{*}{ Name } & \multicolumn{5}{|c|}{ Naphthens UV } \\
\cline { 2 - 6 } & mono & bi & tri & tetra & Penta \\
\hline $\begin{array}{c}\text { Gunashli } \\
244\end{array}$ & 86.77 & 2.92 & 0 & 4.91 & 5.4 \\
\hline
\end{tabular}

\begin{tabular}{|c|c|c|c|c|c|}
\hline \multirow{2}{*}{ Name } & \multicolumn{5}{|c|}{ Naphthens UV } \\
\cline { 2 - 6 } & mono & bi & tri & tetra & penta \\
\hline $\begin{array}{c}\text { Gunashli } \\
250\end{array}$ & 71.79 & 1.12 & 0.58 & 16.21 & 8.71 \\
\hline
\end{tabular}

Fig.11.The naphthenic oil passport of Gunashli square - 244, 250

\section{Conclusion}

Conducted GC / MS, ICP / MS, UV, STA studies suggest that the Gunashli field oil in the Caspian Sea was formed mainly in marine sediments in which sedimentation and diagenesis occurred in a reducing environment.Oil belongs to the ferruginous type, it is characterized as light, medium catagenetic transformation. The values of the sterane parameter dia / reg allow us to judge the clayiness of the oil-mother sedimentary rocks. It was shown that the hydrocarbon composition of oil samples varies depending on the horizon and the depth of occurrence.

According to the data of chromatography-mass spectroscopy, the relative distribution of n-alkanes to oil was determined to calculate the naphthenic oil passport from various horizons and depths. Thus, oil accumulations related to the Middle Pliocene in the Caspian Sea, characterized by a number of geochemical parameters and a complex of hydrocarbon biomarkers, make it possible to predict the composition and prevailing type of oil in deposits with a similar geological structure, and with the help of the ME it is possible to assume the type of initial organic matter as well as the paleographic environment of its accumulation.

\section{References}

[1]. Мартынова Г.С., Максакова О.П., Нанаджанова Р.Г.,, Али-заде А.Э., Мухтарова Х.З. Геохимическая дифференциация нефти месторождения Гюнешли. East European Scientific Journal N9, 2016, p.120-127.

[2]. ГлумовИ. Ф., МаловицкийЯ. П., НовиковА. А., СенинБ. В.. Региональная геология и нефтегазоносность Каспийского моря. - М.: ООО «Недра-Бизнесцентр», 2004, 342 с. 
[3]. Гордадзе Г.Н., Гируц М.В., Кошелев В.Н.. Органическая геохимия углеводородов. 2013. РГУ Москва. Книга 2, с.61-63.

[4]. Peters K.E., Moldovan J.M. Effect of source, thermal maturity and biodegradation on the distribution and isomerization of homohopanes in petroleum//Org. Geochem. - 1991. - V. 17. - No. 1. - P. 47-62.

[5]. Peters K.E., Walters C.C., Moldovan J.M. The Biomarker Guide, 2nd Edition. Vol. I. Biomarkers and Isotopes in the Environment and Human History. Cambridge University Press. - 2005. - 471 p; Vol. II. Biomarkers and Isotopes in Petroleum Exploration and Earth History. Cambridge University Press, Cambridge. $-2005 .-679$ p.

[6]. Grantham P. Sterane isomerization and moretane/hopane ratios in crude oils derived from tertiary source rocks//Org.Geochem.1986.-V.9.- P.295.

[7]. Grantham P.J., Wakefield L.L.Variation in the sterane carbon number distribution of marine source rock derived crude oils through geological time//Org.Geochem.- 1988. -V.12. - P. 61-73.

[8]. Чахмахчев В.А. Геохимия процесса миграции углеводородных систем. - М.: Недра, 1983. - 231с.

[9]. Петров Ал.А. Углеводороды нефти. - М.: Наука, 1984.- 264 с. 